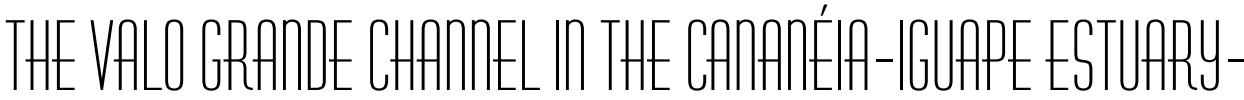

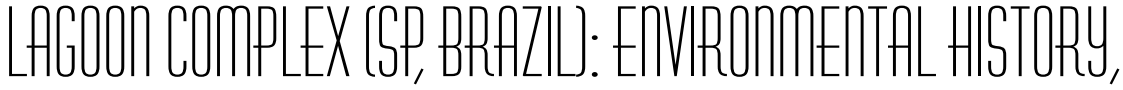 ECOLOCY, AПD EUTURE PERSPPECTIVES'
}

\author{
HELBERT MEDEIROS PRADO \\ MARCELO NIVERT SCHLINDWEIN ${ }^{3}$ \\ RUI SÉRGIO SERENI MURRIETA ${ }^{4}$ \\ DANIEL RODRIGUES DO NASCIMENTO JUNIOR ${ }^{5}$ \\ ELIEL PEREIRA DE SOUZA ${ }^{6}$ \\ MARILIA CUNHA-LIGNON ${ }^{7}$ \\ MICHEL MICHAELOVITCH DE MAHIQUES ${ }^{8}$ \\ PAULO CÉSAR FONSECA GIANNINI ${ }^{9}$ \\ RIGUEL FELTRIN CONTENTE ${ }^{10}$
}

\section{Introdução}

In the nineteenth century, the Ribeira Valley, located between the Brazilian states of São Paulo and Paraná, lived what historians identified as its period of highest economic vigor: the cycle of rice, with its peak in the 1850s (VALENTIN, 2006). Associated with this cycle, in the same time period, there was a significant change in the final course of the Ribeira de Iguape River, or Ribeira for short, with repercussions of high environmental, social, and economic magnitude that last to this day: between 1827 and 1852,

1. The authors thank the following research funding institutions: HMP: FAPESP (2017/25105-0); DRNJ: CAPES-DS (001); MCL: Boticário Group Foundation (Processo BL0006 20121) and CNPq (Processos 472419/2011-0 and 445418/20141); PCFG: CNPq (308772/2018-0 and 428341/2018-7) and FAPESP (2009/54232-4). HMP also thank Antonio Vicente Pretti for sharing his wide knowledge about Iguape area and its history.

2. PhD in Ecology, Visiting Professor at the Federal University of São Carlos, helbertmedeirosprado@gmail.com, https:// orcid.org/0000-0002-2878-317X

3. PhD in Biological Sciences (Zoology), Professor at the Federal University of São Carlos, mnivert@ufscar.br

4. PhD in Anthropology, Professor at the University of São Paulo, murrietarss@gmail.com

5. PhD in Geosciences, Professor at the Federal University of Ceará, daniel.rodrigues@ufc.br

6. Master in Environmental Sciences, Environmental Analyst of Chico Mendes Institute for Biodiversity Conservation, eliel.souza@icmbio.gov.br

7. PhD in Oceanography, Professor at the São Paulo State University, cunha.lignon@unesp.br

8. Full Professor in Oceanography of University of São Paulo, mahiques@usp.br

9. Full Professor in Geosciences of University of São Paulo, pcgianni@usp.br

10. $\mathrm{PhD}$ in Oceanography, Professor at the Federal Institute of Education, Science and Technology of Pará, riguel. contente@gmail.com 
a canal was built between the Ribeira River and the Mar Pequeno estuarine bay, next to the urban core of the city of Iguape. This canal is presently known as Valo Grande (VG) (Figure 1). It was intended to facilitate the movement of the rice production to the old port of Iguape (YOUNG, 1903; COMISSÃO GEOGRAPHICA e GEOLÓGICA de SÃO PAULO, 1914; BESNARD, 1950) ${ }^{11}$.

\section{Figure 1 - Cananéia-Iguape Estuary-Lagoon Complex region.}

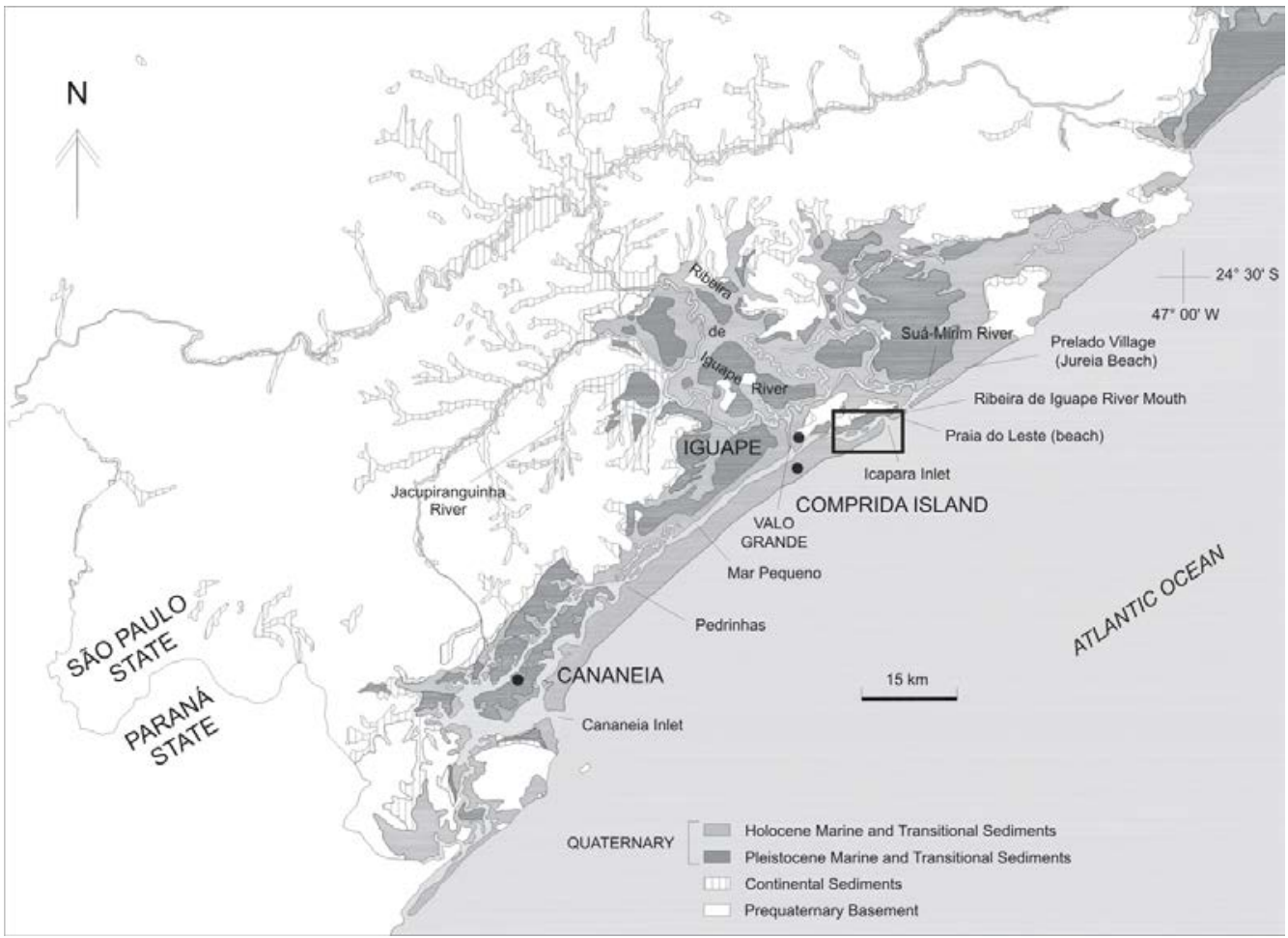

Source: Adapted by Nascimento Jr. et al. (2008), from the geological map of the State of São Paulo, Institute of Technological Research (1981).

Legend: The area detailed in Section 2.2 of this article is highlighted in the rectangle.

It is important to highlight that the Ribeira River forms the biggest river basin in the South-Southeastern Brazilian coast. Furthermore, the Cananéia-Iguape Estuary-Lagoon Complex (CIELC), where VG lies, is considered one of the biggest nursery grounds of marine and terrestrial species of the South Atlantic (MMA, 2006). Indeed, this area holds a great diversity of ecosystems and associated biodiversity, which are presently demarcated as the Mosaic of Protected Tidal Wetland Areas. Created in 2006, the Mosaic covers 34 conservation units of different categories between the southern coast of São Paulo and the coast of Paraná (MMA 2006).

11. There was also a project by Mennucci (1930) to continue the VG toward the SE, crossing Comprida Island. 
CIELC also forms a part of the Atlantic Rainforest Biosphere Reserve and the Natural World Heritage Site, recognized by UNESCO in 1991 and 1999, respectively. The region still expresses rich sociocultural diversity, sheltering human populations from different historical origins, such as the quilombolas (descendants from runaway African slaves), Indigenous Peoples, Caiçaras (populations of mixed Amerindian, African and European origin from coastal São Paulo and Paraná), and Japanese immigrants (SANTOS; TATTO, 2008).

It was in this environmental context of rich natural and cultural heritage that one of the greatest environmental disasters ever recorded on the Brazilian coast occurred and is perpetuated: the opening of the VG canal (GIANNINI et al., 2018). It is noteworthy that the academic knowledge regarding the problem involving the VG is highly dispersed across several disciplines and subdisciplines, which has hindered a comprehensive approach to the issue.

Given these initial considerations, the primary objective of this article was to produce a synthesis that reveals the core aspects of the problem involving VG in the CIELC. To this end, a review of the academic literature on the subject was conducted, including the studies developed by most of the authors who wrote this article, who have been addressing this problem for years. Taking a multidisciplinary approach, this article will emphasize the following aspects of the problem: (1) the historical and economic moment of the Ribeira Valley at the time VG was opened; (2) the role of VG in geomorphological and estuarine vegetation changes in the region in the last 150 years; (3) the input of pollutants and the presence of heavy metals reaching the CIELC via VG; (4) the consequences of opening VG on the physicochemical conditions of the system and the biota; and (5) the human aspects of the issue, in terms of local perception and economy, and of the political sphere regarding the environmental governance in that region.

\subsection{Domesticating rivers: an old tale}

It is important to consider that the VG channel forms part of a long historical process of anthropogenic changes in the natural course of rivers that has marked numerous societies in different historical periods. Indeed, rivers have always played a central role in human history, whether as a source of energy and food or as a means of transportation.

In Mesopotamia, Egypt, and China, where the first states emerged as a form of complex sociopolitical organization, the diversion of large rivers (such as the Nile, the Tigris, the Euphrates, the Indus, the Yangtze, and the Yellow) for flood control and expansion of arable land resulted in high social and environmental costs to those civilizations (ELVIN, 2004; BARNES, 2014). In Europe, the relationship between erosion caused by deforestation and agricultural expansion and the siltation of coastal regions where the Po, Tiber, Rhône, and Ebro rivers flowed appeared clear to Greek and Roman historians (THOMMEN, 2012).

Similar processes to those described above can also be observed in Mesoamerica and the Andes, among the Inca and Mexica empires, and the Mayan city-states (DEMAREST, 2004; QUILTER, 2014). As early as the eighteenth century, one of the main 
elements driving the Industrial Revolution was the construction of a large 3,600-km river canal system in England, which greatly contributed to the lead the country had in that important historical moment (FERNANDEZ, 1995).

In Brazil, the most emblematic cases of river course changes are those associated with the construction of hydroelectric dams in the Amazon, such as Tucuruí (Tocantins River, State of Pará) and Balbina (Uatumã River, State of Amazonas) in the 1980s and Belo Monte (Xingu River, Pará) in the 2000s (Hemming, 2011). The breach of a dam in Mariana (State of Minas Gerais) in 2015, with an ecological, social, and human-health impact extending to the Atlantic Ocean, is already considered the largest environmental disaster in Brazilian history (Fernandes et al., 2016). The rupture of one of the Feijão Creek mine dams (Brumadinho, Minas Gerais) in January 2019 was even more tragic in terms of the human lives lost, accounting for 233 deaths as of May 1, 2019 (Minas Gerais State Protection and Civil Defense Bulletin No. 122, of May 2, 2019) ${ }^{12}$.

Another example of significant changes to a river in the Brazilian context is the monumental work of transposition of the São Francisco River between 2006 and 2017. This work may have its long-term sustainability and effectiveness compromised due to the lack of a comprehensive study and a program of the revitalization of this river (SILVA, 2014). The case of VG, the subject of analysis of this article, dates from the early nineteenth century and represents a singular example of diversion of the natural course of a river in Brazil. Its tragic environmental and social consequences have been amplified over the past 150 years, and yet they remain unresolved.

\section{Valo Grande in its numerous dimensions and implications}

\subsection{Historical aspects involving the construction of VG}

First, it is imperative to mention that the work that would result in VG had the main objective of facilitating the movement of rice production to the old port of Iguape in the mid-nineteenth century, during the peak of the rice economic cycle in this region (YOUNG, 1903). Initially termed "Valo do Rocio," by the time the work was completed, the dimensions of the VG were just over 4-m wide, 2-m deep, and 3-km long. However, just a few years after its opening, an intense erosion process of its banks had already begun, with the consequent carrying of a large volume of sediments to the Mar Pequeno channel (Figure 1) (NASCIMENTO Jr. et al., 2008; GIANNINI et al., 2018).

It should also be noted that Iguape was one of the most important ports in the Brazilian Empire throughout most of the nineteenth century (VALENTIN 2006). It is noteworthy that the transformations in VG, notably its enlargement and the amount of sediment that started entering Mar Pequeno, were already noticeable among the residents of Iguape in the first years after its completion (YOUNG, 1903). This perception was also expressed in the form of concern of the local population regarding the siltation of Mar Pequeno and its potential implications for the viability of the old Iguape port in the future.

12. Source: <http://www.defesacivil.mg.gov.br/index.php/defesacivil/boletim-defesa-civil>. 
As an example of this concern of the Iguape population, we can mention the letter from the Iguape City Council to the provincial government of São Paulo in 1861, only nine years after the opening of the canal. On that occasion, based on a request from the French resident of Iguape Louis Krecherly, the City Council was trying to send to the provincial government a formal request to send a commission of engineers to analyze and indicate possible solutions for the siltation of the Mar Pequeno lagoon, which was already visible during those early years after VG was opened (YOUNG, 1903; VALENTIN, 2006).

In fact, as a result of the erosion of its banks in the decades following its construction, the canal was becoming increasingly wider. Starting at just over $4 \mathrm{~m}$ at its inauguration in 1852, in 1950 its width would reach $200 \mathrm{~m}$. Its present dimensions correspond to approximately 250-m width and 7-m depth (NASCIMENTO Jr et al., 2008).

In the course of this process, rice production declined in the region and the former port of Iguape was closed. These historical events seem to be related to the opening of VG and the consequent siltation of Mar Pequeno, making it difficult to navigate. However, there is still no consensus among historians as to the causal relationships between the opening of VG, the impossibility of mooring large vessels in the old port of Iguape, its closure, and the decadence of the rice cycle in the region (VALENTIN, 2006).

\subsection{Geomorphological and vegetation changes}

Connected to the issue involving the old port of Iguape, there are also studies demonstrating the influence of the VG opening on the acceleration of the growth of Comprida Island and the erosion of the beach at Praia do Leste in the last 150 years (Figure 2). VG caused most of the Ribeira River's waters to flow seawards via Mar Pequeno and its inlet (termed the Icapara inlet), which increased both the hydraulic flow at this inlet and the sediment input on the adjacent coast. In the first decades after the opening of VG, this extra supply of sediments generated the enlargement ("fattening") of Comprida Island, due to the containment of the inlet by the Icapara Hill, supported by crystalline rocks. Owing to the island's own increase in width, the Icapara inlet overcame this obstacle and began to move towards Northeast through the erosion of the sandy beach sediments of Praia do Leste, thereby creating accommodation space for the longitudinal growth of Comprida Island in the same direction (Figure 2) (NASCIMENTO Jr. et al., 2008; GIANNINI et al., 2009, 2018).

Nascimento Jr. et al. (2008) reported that between the eighteenth century and the year 2000, the northern inlet of Mar Pequeno (i.e., the Icapara inlet) shifted approximately $5.5 \mathrm{~km}$ towards northeast. Between the years 1962 and 2000, this displacement reached $912.5 \mathrm{~m}$. In the same period, the extension of the beach at Praia do Leste was reduced by $570 \mathrm{~m}$ (Figure 2).

Having taken between five and six thousand years for its natural formation (before VG was opened) (GIANNINI et al., 2009), it stands out that approximately $10 \%$ of the present 63-km length of Comprida Island (GUEDES et al., 2011) was formed just in the last 130 years, at an average rate of approximately $27.5 \mathrm{~m}$ per year (GIANNINI et al., 2009). Meanwhile, at the VG mouth on Mar Pequeno, increasing amounts of sediment silted the estuary as a whole, forming new sandbanks (ITALIANI; MAHIQUES, 2014) and finally producing an intra-lagoon delta in the area (MAHIQUES et al., 2014; GIANNINI et al., 2018). 
Another effect of the opening of VG was a downstream decrease in the flow of the Ribeira River, which began to silt. As a result, the lower course of the river, which before the opening of VG was where the Suá-Mirim River flows today (Figure 1), shifted to its present position, about $3 \mathrm{~km}$ south (BENTZ, 2004; GIANNINI et al., 2018), seeking for the shortest path to the sea.

Also, the longshore drift (wave-induced sediment transport along the coast), which travels regionally to the Northeast, was then blocked by the Icapara inlet water jet flow. Thus, a stretch of Juréia beach northeast of the Icapara inlet had the longshore drift inverted to the southwesterly direction. This local inversion of the drift progressively pushed the mouth of the Ribeira southwest, with the simultaneous growing of a 3-km long sand spit (ALCÁNTARA-CARRIÓ et al., 2018). Thus, since the opening of VG, Icapara inlet and Ribeira River mouth display a tendency to move in convergent directions (Figures 1 and 2), until they met in 2009 (ARAGON, 2017).

The Suá-Mirim River mouth region (Figure 1), which before VG received sediments from the Ribeira River and presented a convergence of the longshore drift, with a tendency of deposition, now presents drift divergence (towards southwest in the southern section, in the domain of the inverted drift cell, and towards northeast in the northern section) and, therefore, has a tendency to lose sediments (BENTZ, 2004). This fact explains the intense erosion in this portion of the Juréia beach. Because of this, the remains of the former chapel and cemetery of the village of Prelado (Figure 1), built before 1920, are under the sea today (GIANNINI et al., 2018).

Figure 2 - Historical record of morphological changes around the Icapara inlet, approximately $7-\mathrm{km}$ east of the Valo Grande canal since the late eighteenth century.
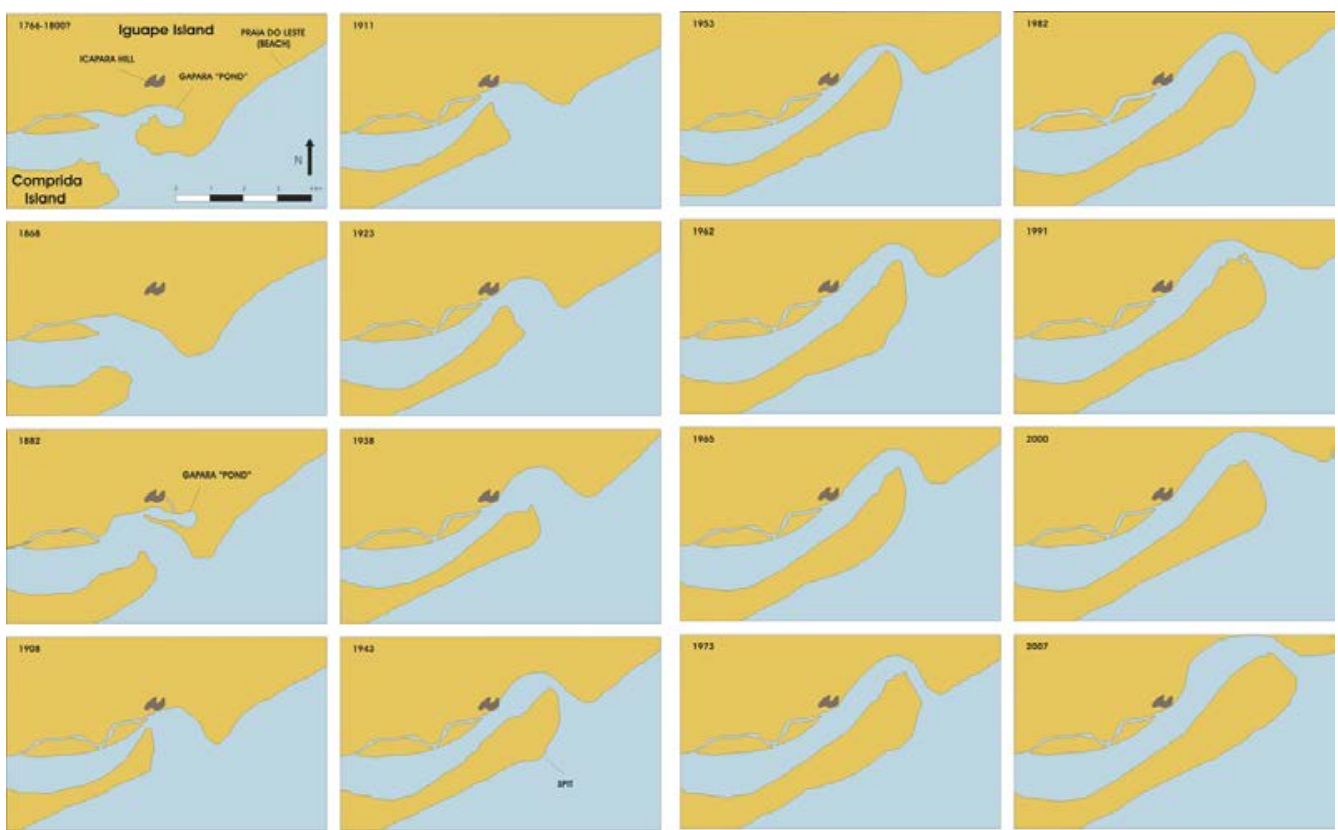

Source: Based on studies by Nascimento et al. (2008) and Aragon (2017). 
In the process of carrying water and sediment from the Ribeira River to Mar Pequeno via VG, the CIELC receives an increasing volume of continental waters every year (MAHIQUES et al., 2009), thus reducing the salinity of the estuary and compromising the permanence of mangroves in the area (CUNHA-LIGNON; KAMPEL, 2011; CUNHA-LIGNON et al., 2011). This entering of continental waters into Mar Pequeno has caused important changes in the landscape configuration and the conditions of the estuarine ecosystem in question. An example of the modifications mentioned is the formation of aquatic macrophyte banks around the mangrove islands present in the area, especially in the last two decades (Figure 3).

Figure 3 - Evolution between 1999 and 2010 of aquatic macrophyte banks around mangrove islands (Iguape, SP).

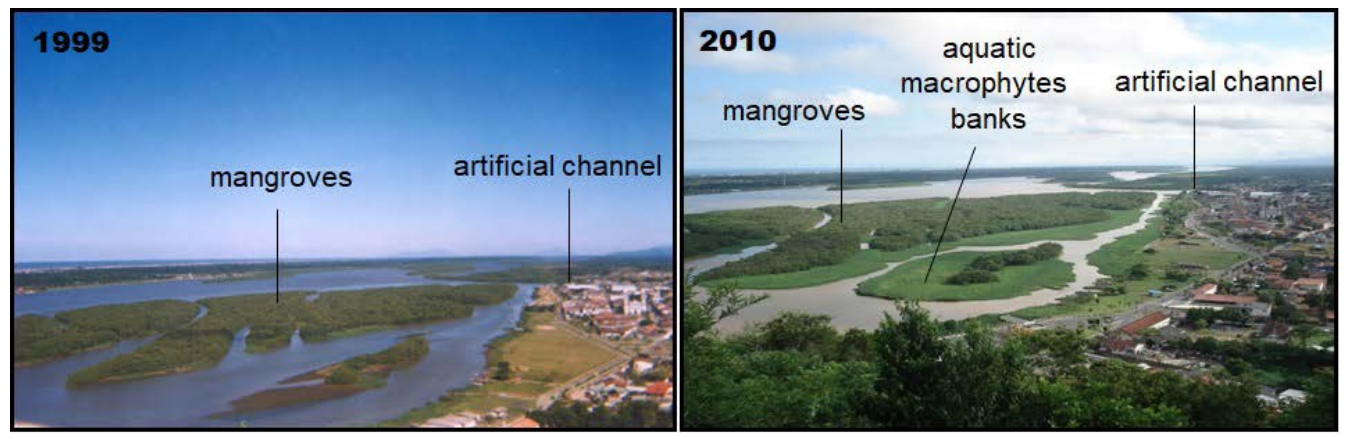

Source: Adapted from Cunha-Lignon; Kamper (2011).

Using remote sensing techniques and covering part of the final course of the Ribeira River, the VG canal, and the Mar Pequeno lagoon, Cunha-Lignon and Kampel (2011) recorded significant increases in macrophyte banks between 1997 and 2010. In the analysis performed in 1997, the occurrence of aquatic macrophytes in the region corresponded to an area of 226 hectares (ha), present primarily on the banks of the Ribeira River, and absent in the coastal zone (Mar Pequeno). In 2010, this feature in the landscape reached an area of 329 ha, and almost all of this increase corresponded to the appearance of aquatic macrophyte banks around mangrove islands in Mar Pequeno (CUNHA-LIGNON; KAMPEL, 2011). Such banks are composed primarily by the species Pistia stratiotes L., Salvia sp. L. and Eichhornia crassipes Mart. Solms, all considered biological indicators of altered or degraded areas (CUNHA-LIGNON; KAMPEL, 2011).

\subsection{Pollutant level and presence of heavy metals in the system}

In addition to changes in morphology (sandbank formation) and decreased salinity, it is also important to mention the transport to the CIELC via the VG canal of pollutants generated and disposed of along the entire length of the Ribeira River. This leads to a brief introduction to the main polluting activities in the Ribeira Valley region over the last centuries. 
The earliest records of gold and silver exploration in the upper reaches of the Ribeira River date back to the seventeenth century (YOUNG, 1902). Such activities would persist, to a greater or lesser extent, in different periods and on different stretches of the river until the first half of the twentieth century. Since 1945, the primary generator of pollutants in the Ribeira River was the mining company, Plumbum Mineração e Metalurgia Ltda., with its headquarters in the Paraná municipality of Adrianópolis, which interrupted its activities in 1995 (MAHIQUES et al., 2009; MARTÍNEZ et al., 2013).

Combining sedimentological, chemical, and biological indicators, geochronology, and heavy-metal analysis, Mahiques et al. $(2009,2013)$ recorded an immediate increase in the concentrations of zinc $(\mathrm{Zn})$, chromium $(\mathrm{Cr})$, copper $(\mathrm{Cu})$, and lead $(\mathrm{Pb})$ in the CIELC in a period coinciding with the inauguration of VG in 1852. In particular, the lead input increased, especially after 1945, the year when the Plumbum mining company began its activities in the upper reaches of the Ribeira River.

It should be noted that even after this mining company was closed in 1995, lead still leaches into the estuarine system, probably due to the continued weathering of the Ribeira River substrate layers, which continue to be eroded (MAHIQUES et al., 2013). Also noteworthy is the fact that the levels of $\mathrm{Zn}, \mathrm{Cr}, \mathrm{Cu}$, and $\mathrm{Pb}$ in CIELC are in a similar order of magnitude (if not higher, as in the case of $\mathrm{Pb}$ ) to that of the highly polluted Santos estuary, the most industrialized coastal region of Brazil. Also, Tramonte et al. (2018) indicated $\mathrm{Pb}$ availability in both surface and subsurface sediments, reinforcing the argument that the CIELC became a highly concentrated deposit of contaminated sediments after the opening of VG.

It is also possible to mention the amount of organic matter brought into the Ribeira River in the form of urban sewage and agricultural fertilizers, as well as the substances that make up the pesticides used in conventional agriculture in the region. In this regard, Barrera-Alba et al. (2007) were able to record, in the portion of the CIELC near VG, a phosphorus concentration approximately 100 times higher than that allowed by the present legislation. This finding led the authors to suggest that a process of anthropogenic eutrophication of the water system in the region was underway in that portion of the CIELC at the time of the study. The high levels of phosphorus in the waters of the region could result from the uncontrolled discharge of this element by the company Bunge S/A (Bunge-Cimpor-Fosbrasil mining-industrial complex) in the Jacupiranguinha river basin (MOCCELLIN, 2006).

\subsection{Physicochemical conditions of the system and the biota}

As indicated so far, the environmental changes in the CIELC resulting from the opening of VG in 1852 and its subsequent widening have been significant and ecologically deleterious, reconfiguring the landscape and disrupting the region's ecosystem. Another important aspect of these transformations is the constant contribution of about $70 \%$ of the Ribeira River water volume, which is presently diverted via VG to the CIELC, resulting in an estuarine environment that is currently under low salinity conditions, especially near the VG mouth on Mar Pequeno (MAHIQUES et al., 2009). 
Still regarding the physicochemical conditions of the system, Braga and Chiozzini (2008) found high levels of nitrite in Mar Pequeno in 2005, when VG was already completely reopened. Nitrite is an intermediate form of nitrogen that is rarely accumulated under natural conditions. Thus, its accumulation suggests an imbalance in the biogeochemical cycles in the region, in addition to being toxic to the biota as a whole. Another relevant fact is that the collections by Braga and Chiozzini (2008) were performed in the southern region of the CIELC, near the city of Cananéia (State of São Paulo). This shows the extent of the influence of VG on the physicochemical conditions of the system in a $40-\mathrm{km}$ radius from its mouth on Mar Pequeno (Figure 1).

In terms of benthic fauna, Mahiques et al. (2009) were able to record the extinction of calcareous foraminifera in the period following the opening of VG. Complementarily, while recording mollusk species as bioindicators in samples of sediment columns from Mar Pequeno, Martínez et al. (2013) found significant historical changes in the abundance and composition of this fauna, which coincide with the opening of VG in 1852, its closure in 1978, and its reopening in 1983.

The study by Martínez et al. (2013) reveals, roughly speaking, a significant loss of marine and euryhaline mollusk species shortly after the opening of VG in 1852. These results also show the persistence and dominance of species tolerant of highly degraded and polluted environments (for example, Heleobia cf. australis) in the period after VG was opened, especially at points near its mouth on the Mar Pequeno lagoon.

VG has also disrupted the CIELC fish community, primarily due to the drastic decrease in salinity in the system (CONTENTE, 2013). This low salinity would act as an osmotic barrier for the occurrence in the CIELC of resident estuarine species and those migrated from the sea. One of the results evidenced by the same author is the low species diversity and the predominance of freshwater species in the vicinity of VG. This ecological disruption of the estuarine system may be related to an apparent increase in the generalist fish population, such as the catfish Cathorops spixii, which has no commercial and fishery value. Because this is a generalist species, it may have an advantage over other catfishes with commercial value (for example, Genidens barbus), which means that local fishing activity is impaired.

The large input of sediment carried by the canal has also led to the silting of many gamboas (marginal tidal creeks), causing the loss of essential habitats to the larval and juvenile phases of many fish species, including those of high fishing interest, such as the fat snook (Centropomus parallelus). Thus, the ecological function of this estuary as a critical area for the early life stages of the ichthyofauna seems to be significantly compromised (CONTENTE, 2013).

Lastly, in an ethnoecological study in the Pedrinhas neighborhood on Comprida Island, located next to the Mar Pequeno lagoon, about $35 \mathrm{~km}$ southwest of VG, Gusmão (2013) recorded reports of local fishers identifying VG as a major threat to the permanence of sea turtles in the estuarine-lagoon system, especially the green turtle (Chelonia mydas) (GUSMÃO, 2013). This is because the low salinity caused by VG would reduce the number of algae and marine angiosperms that make up the diet of this species. It is worth mentioning that the CIELC represents an important feeding and development area 
for juvenile green turtles from different origins, including the British Ascension Island, in the South Atlantic, and Suriname (BONDIOLI, 2008).

\subsection{Human dimension}

\subsubsection{Impacts on fishing and adaptive changes of the local population}

The economy of the Caiçara and other riverine communities from the CIELC is known to have been primarily based on fishing, although supplemented by agriculture, the extraction of non-timber plant products, and more recently tourism (HANAZAKI et al., 2007). Among the few studies involving the relationship between VG and the fishing activity (small-scale or commercial) in the region, it is possible to cite the analyses by Oliveira (2011). The author could observe, for example, that the diversity of fish resources in the vicinity of the city of Cananéia (23 species in total), with less influence from VG, was higher than that of Iguape (16 species in total).

Oliveira (2011) also showed that in the context of Cananéia, the focus seems to be more on offshore breeding species, such as the Atlantic seabob (family Penaeidae) and the mullet (Mugilidae). The white mullet (Mugil curema) is another species that is widely exploited through trap-net fishing in Cananéia (CONTENTE, 2013). In Iguape, the two most sought-after species, the Broadband anchovy (Anchoviella lepidentostole - Engraulidae) locally known as manjuba and the fat snook, both may migrate up the river to reproduce.

Also, the manjuba is noticeably the most highly-valued resource by the fishermen of Iguape, without even being included among the 23 aquatic resources considered most important for Cananéia fishers (OLIVEIRA 2011). Compilations of historical data are still scarce, but those available suggest that manjuba fishing only became an important economic activity in the region after the opening of VG. This species, which swims up the Ribeira River as part of its reproductive behavior, used to do so only through the river mouth (BENDAZOLI; ROSSITSCHOWSKI, 1990). Thus, with the opening of the canal, VG and Mar Pequeno became new habitats for manjubas, and almost all the fishing effort in Iguape became concentrated in these new environments.

Complementarily, Cunha-Lignon et al. (2017) also recorded a greater diversity of fishery resources in the region near Cananéia, compared to the northern portion of the CIELC. This pattern is associated with the greater diversity in the fishing gear used in Cananéia, rather than the simplification found in Iguape, under greater influence of VG waters (CUNHA-LIGNON et al., 2017). The study of the forms of adaptive adjustment of local populations to the environmental transformations associated with VG is still an important knowledge gap regarding the problem of VG in its human dimension.

\subsubsection{Local residents' perception of the problem}

Historical records point to some attempts to close VG, such as in 1889 (YOUNG, 1903; ITALIANI; MAHIQUES, 2014) and 1894 (CARNEIRO, 2005). In the case of 1889, an attempt was made to close VG upstream, close to the Ribeira River. A stone 
barrier started to be constructed, but this was aborted shortly before its completion, when it was concluded that it would not be able to contain the force of the waters of the Ribeira River, especially during its periodic floods (ITALIANI; MAHIQUES, 2014).

In the second half of the twentieth century, the first attempt to close VG occurred in 1978 (FURTADO et al., 1981; MISHIMA et al., 1985) (Figure 4A). This happened in the wake of a decade of accelerating growth of the agricultural economy in the Ribeira Valley and infrastructure projects aimed at developing the real estate market in the region. The agenda of the environmental movement, which plans the development of the region according to its rich natural heritage and relevant tourism potential (SOUZA, 2012), also took shape at the end of the 1970s.

In this scenario, the closure of VG aimed at restoring the natural characteristics of the lagoon system, stopping the intense erosion process of its banks (which had reached the urban area of Iguape), and establishing a road connection with the Rocio neighborhood, separated from the rest of the city by the canal (SOUZA, 2012). To this end, a stone-and-sand dike was built in 1978, closing the VG.

However, in 1983, due to heavy flooding of the Ribeira River (MISHIMA et al., 1985; TELES, 1997; CARNEIRO, 2005), the dam gave way partially. This was recovered in subsequent years, and the dam crest was lowered in 1989, but after considerable structural damage, the dam eventually gave way again (SOUZA, 2012) (Figure 4B).

\section{Figure 4. A - Dam in the Valo Grande canal built-in 1978. B - Structure of the da- maged dam in the late 1980 s.}

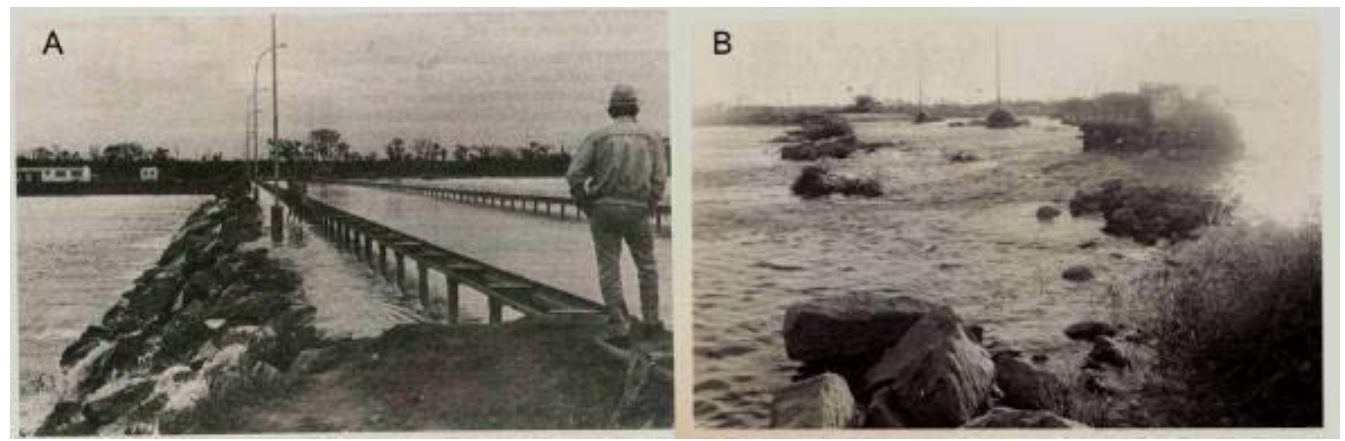

Legend: In both photographs, the upstream portion of the dam is on the right in the image.

Source: Photographs collected by Eliel Pereira de Souza from websites of Iguape residents, without author reference (accessed July 2009).

This sequence of events significantly marked the local economy and politics, affecting upstream and downstream social actors in different ways ${ }^{13}$. In short, the closure of VG in 1978 and the ensuing floods shaped the most significant narratives among the

13. Here, social actors are considered the groups that share identity and look to influence decision-making processes in an articulated manner, according to Habermas (1984). 
social actors of social and environmental conflict that had already been sparked over keeping or removing the work.

An important consequence of this historical period for the region was the significant loss of productivity of manjuba fishing in VG and Mar Pequeno (CARNEIRO, 2005). It is known that with the canal closure, the abrupt increase in salinity in that portion of the CIELC removed the manjuba schools from the Mar Pequeno and VG mangroves, partially compromising the productivity of manjuba fishing in these environments (SOUZA, 2012). During this period, the manjuba fishermen began to work mainly in the Ribeira River channel (CARNEIRO, 2005).

It is also important to mention that during the more than 100 years in which VG remained open, between 1852 and 1978, the Ribeira River channel upstream of VG underwent intense siltation. Thus, when the canal was closed in 1978, this area became more vulnerable to major flooding. In fact, in January 1981 the river waters spilled over the dam structure, and this would happen twice again in 1983 (Figure 4A) (SOUZA, 2012). The large floods that followed the closure of the VG significantly impacted the residents of the river banks, their homes and productive activities, and the significant banana plantations that occupied the Ribeira River floodplains (Figure 5). Thus, those groups would join the manjuba fishermen in defending the removal of the dam.

Figure 5 - Excerpt from an article published in the Tribuna do Ribeira newspaper (January 31-February 6, 1981) under the title "Floods: The Drama of the Homeless."

Iguape is starting to live a social drama whose consequences remain unpredictable. There are numerous beggars on the streets, thousands of homeless people, and few prospects of employment for all these people. Rural exodus is imminent after the new flood. The losses have not been calculated yet, but it is believed that they will cut close to 1 billion cruzeiros. The entire economy of the city is already suffering the consequences from the flood caused by the Ribeira.

Mayor Carlos Fausto says that the city administration has no means to absorb the workforce that is now unemployed. The city's businesses, expecting a crisis, do not have the means for that either. Several families are thinking about the possibility to start working in the fishing sector, but with the current small catch of manjuba when compared to the previous catch, prospects become even dimmer.

These facts explain the reluctance of several rural families to abandon their belongings until the last minute. Those families knew that last February's flood would happen again this year (though nobody expected a greater severity), but they were also aware of the fact that new losses would be definitely irreparable.

Source: Adapted from Carneiro (2005). 
Contrary to the perception of the groups mentioned above, the narrative of fishers from the municipality who do not specialize in manjuba fishing treats the period after closure as beneficial for fishing. Their perception is that, with the VG closure, other fish species reappeared in Mar Pequeno, allowing diversification of fishing activities and a better distribution of efforts over the year. With VG dammed, some Iguape fishermen became less dependent on the manjuba catch season. This group is aligned with the environmental sector, the academic community in general, and the city's Commercial Association, the latter mobilized by the possible increase in tourism if the CIELC's ecological conditions are to be restored (SOUZA, 2012).

\subsubsection{Political and legal aspects of the issue}

In the context of public policies, the 1981 National Environmental Policy, the National Coastal Management Plan (1987), and later the National Water Resources Policy (1997), structured a normative-institutional arrangement from which policies aimed at the management of the CIELC could be devised. The São Paulo State Council for the Environment (CONSEMA), the Executive Committee for Integrated Studies of the Ribeira de Iguape Basin (CEEIGUAPE), the Coastal Management Sectorial Group (GS-CELIC), and the Ribeira de Iguape River Basin Committee (CBH-RB) were also important in establishing a political arena ${ }^{14}$ for discussions around the VG issue (SOUZA, 2012).

With the construction of the dam in 1978 and the successive floods of the early 1980s, disputes over keeping or removing the dam occurred in parallel at CONSEMA and CEEIGUAPE. Of the most significant alternatives presented and discussed in CEEIGUAPE until 1984, the construction of a sluice dam with floodgates and a lock was chosen as the most appropriate, and dike crest lowering was considered as a palliative and mitigating measure against the effects of flooding. The floodgate installation project aimed to control the flow of freshwater to be allowed in the estuary under extreme flooding regimes and to mitigate its upstream effects (SOUZA, 2012).

Expected to be completed in two stages, involving the construction of a spillway dam and later the installation of floodgates, the work began in 1990 by the State of São Paulo Department of Water and Electricity (DAEE) (Figure 6A) and the first stage was finished in 1993 (Figure 6B). The subsequent phase, in which floodgates would be installed, was not performed. During this period, the flow of VG remained partially interrupted only by the cofferdams, which, due to the lack of maintenance, were damaged by successive spills until their complete rupture in 1995 (SOUZA 2012).

Later, in the 2000s, an event would trigger the start of another important episode in this process. It was a landslide on the built-up left bank of VG in 2006. This event motivated the state government to create a commission of technicians to elaborate a diagnosis that would allow the execution of the second stage of the dam (the spillway construction), as well as a rule for the operation of the floodgates (DAEE, 2011).

14. The political arena concept here is taken as the context in which a given decision-making process unfolds in terms of expectations and predispositions of the social actors involved and of the distribution of antagonistic and convergent interests at play (Frey, 2000). 


\section{Figure 6. A - Beginning of the construction of the sluice dam on the Valo Grande canal in 1990. B - First stage of the work completed (2005 photo).}

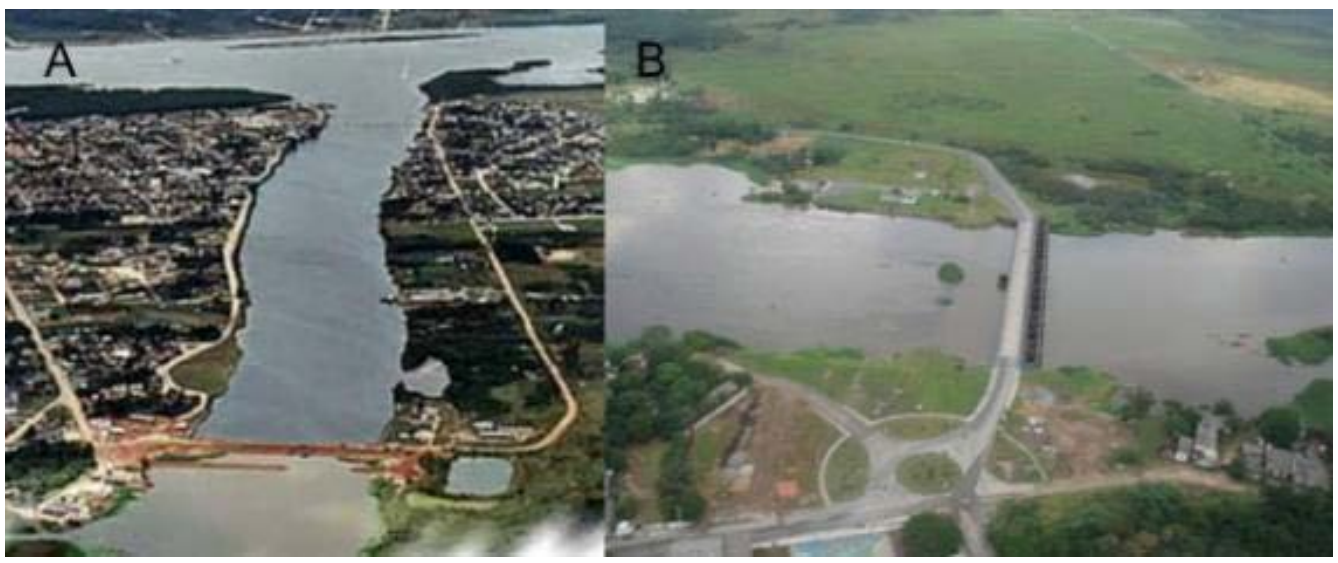

Source. A: Image available at < https://diariodeiguape.com/2007/12/03/baurragens-3/> (accessed July 2009). B: Eliel Pereira de Souza, personal archive.

The São Paulo State Public Prosecutor Office (MPE), however, considered that the surveys conducted had been insufficient for proper decision-making. After unsuccessful attempts to negotiate with the São Paulo state government, seeking an adjustment of conduct, the MPE sued the government with a Public Civil Action in 2007. This action questioned the abandonment of the hypothesis of definitive closure of VG by the state government and held it responsible for the degradation of the CIELC.

The lawsuit was accepted and received a preliminary injunction in favor of the MPE in 2007. The state then filed a request for suspension of this decision with the Federal Supreme Court, which denied it in an order dated December 18, 2014. In 2017, the final lower-court decision was favorable to the MPE, determining the immediate start of works to close the VG by the State of São Paulo. Next, the state government appealed the decision to a higher court in Case 0002225-57.2011.8.26.0244. More recently, a ruling of the São Paulo State Court of Justice (TJSP) on November 8, 2018, partially confirmed the lower court's decision mandating the closure of the channel. This same decision also accepted the possibility of operating the gates for 10 years, making it possible to perform adjustments and adaptations in the system over this period.

It is also important to mention that the aforementioned Public Civil Action conditioned the closure of VG to a previous rectification of the Ribeira River's terminal course, aiming to mitigate the impact of floods on the populations that live there ${ }^{15}$. It should also be noted that the latest decision by the TJSP seems to align with the alternative, suggested in DAEE (2011), of gradual accommodation of the Ribeira River (and its channel) in its terminal course (between VG and its mouth), closing VG only partially. This process would occur through the operation of floodgates that still need to be installed in the area.

15. Caveat already present, among other reports, in DAEE (2011). 
However, there are no studies so far that could provide practical support and technical security for this measure (SOUZA; OLIVEIRA 2016).

Considering the VG closure scenario, it would be necessary to implement in the region measures such as: mapping flood risk areas; regulating and enforcing land use and occupation in the floodplains; implementing flood protection policies; and conducting long-term ecological monitoring to verify the effectiveness of these interventions for the recovery of the estuarine ecosystem in question (FURTADO et al., 1981; DAEE, 2011; SOUZA, 2012).

\section{Final considerations}

Between the second half of the nineteenth century and the beginning of the twentieth century, VG was widened and its impacts on the region were greatly amplified. As part of this process, the CIELC became an ecologically disrupted estuary in its northern portion (CONTENTE 2013), and a deposition site of contaminated sediment, including heavy metals at alarming levels (MAHIQUES et al., 2009, 2013; TRAMONDE et al., 2018). In this regard, it is surprising that there are no studies on the impact of this contamination on human health in the region.

Among the important geographic alterations resulting from VG, the erosion in the southern portion of Juréia beach and the destruction of the Praia do Leste plain in Iguape stand out for their direct effects on the respective local populations (ARAGON, 2017; GIANNINI et al., 2018). The lack of studies on the adaptive adjustments of local coastal populations in the face of such changes and on how the public power has acted in this process is also noteworthy.

As noted above, the environmental damage of VG is alarming, and positive changes to the CIELC due to its closure have already been experienced. On the contrary, the social and economic impact that may result from its closure is not negligible, as shown by the traumatic experience of its closure between 1978 and 1983 (FURTADO et al., 1981; SOUZA, 2012; SOUZA; OLIVEIRA, 2016). Considering the studies presented in this article and the complexity of the problem that they expose, it can be understood that medium- and long-term strategies to mitigate the impact on the CIELC must go further than just structural works (such as floodgate installation) and any further legal rulings. In this sense, political and institutional arrangements that effectively integrate institutions and sectors of society that are sensitive to the issue must be considered.

In summary, it is possible to state that the southern coast of the State of São Paulo is today deeply marked by the presence of the VG canal. It should also be noted that the canal remains open 157 years after the first official warning of the problem (YOUNG, 1903), despite the accumulation of scientific knowledge already produced on the issue. In this regard, the current fragmentation of the scientific knowledge about VG seems to be part of the limitations in dealing holistically and effectively with the problem. This article aims to contribute to overcoming this difficulty.

It is also surprising that the issue of VG remains unresolved, despite the already constituted normative and institutional system that regulates environmental policies in 
Brazil in all three spheres (municipal, state, and federal) of government (MITTERMEIER et al., 2005). From the holistic view of the issue that this article has sought to develop, the decision for an initial partial closure of the canal via a floodgate scheme seems the most appropriate now. Should such a measure be implemented by the São Paulo state government, following the latest court ruling on the issue (Section 2.5.3 of this article), it may mark the beginning of an environmentally reasonable solution for the CIELC, without the sense of social responsibility being lost during this process.

\section{References}

ALCÁNTARA-CARRIÓ, J. et al. Two new conceptual models for the formation and degradation of baymouth spits by longshore drift and fluvial discharge (Iguape, SE Brazil). Earth Surface Processes and Landforms, 2018. Disponível em: (https://doi.org/10.1002/ esp.4279).

ARAGON, C. C. Morfodinâmica das Desembocaduras de Icapara e do Ribeira de Iguape, São Paulo. 2017. 128f. Dissertação (Mestrado em Oceanografia Geológica) Universidade de São Paulo.

BARNES, J. Cultivating the Nile: The Everyday Politics of Water in Egypt. Duke University Press: New York, 2014.

BARRERA-ALBA, J. J. et al. Influence of an artificial channel in a well-preserved subtropical estuary. Journal of Coastal Research, n. 50, p. 1137-1141, 2007.

BENDAZOLI, A. et al. A Manjuba (Anchoviella lepidentostole) no rio Ribeira de Iguape: biologia, comportamento e avaliação de estoque. IBAMA/IOUSP/IP-SA/SEMA: São Paulo, 1990.

BENTZ, D. Os cordões litorâneos da planície de Una-Juréia, municípios de Peruíbe e Iguape, SP. 2004. 108f. Dissertação (Mestrado em Geologia Sedimentar) - Universidade de São Paulo.

BESNARD, W. Considerações gerias em torno da região lagunas de Cananéia-Iguape. Boletim do Instituto Paulista de Oceanografia, v.1, n. 1, p. 9-26, 1950.

BONDIOLI, A. C. V.; NAGAOKA, S. M.; MONTEIRO-FILHO, E. L. A. Chelonia mydas: habitat and occurrence. Herpetological Review, v. 39, p. 213, 2008.

BRAGA, E. S.; CHIOZZINI, V. G. Nutrientes dissolvidos no complexo estuarino-lagunar de Cananéia-Iguape: influência do Valo Grande no setor sul (1992 e 2005). Simpósio Brasileiro de Oceanografia 3: Oceanografia e Mudanças Globais. IOUSP, São Paulo, p. 573-582, 2008.

CARNEIRO, R. R. S. A pesca da manjuba (Anchoviella lepidentostole) e o canal do Valo Grande: uma relação de (des)continuidades em Iguape-SP. 2005. 156f. Dissertação (Mestrado em Geografia Humana) - Universidade de São Paulo. 
COMMISSÃO GEOGRAPHICA E GEOLÓGICA DO ESTADO DE SÃO PAULO. Exploração do Rio Ribeira de Iguape. São Paulo, SP, 1914.

CONTENTE, R. F. Padrões ecológicos locais e multidecadais da ictiofauna do estuário Cananéia-Iguape. 2013. 146f. Tese (Doutorado em Oceanografia Biológica) - Universidade de São Paulo.

CUNHA-LIGNON, M.; KAMPEL, M. Análise multitemporal de imagens Landsat para monitoramento de áreas de manguezal: subsídio à gestão costeira do litoral sul do Estado de São Paulo. XV Simpósio de Sensoriamento Remoto. Curitiba, p. 5032-5038, 2011.

CUNHA-LIGNON, M. et al. Mangrove Forests Submitted to Depositional Processes and Salinity Variation Investigated using satellite images and vegetation structure surveys. Journal of Coastal Research, n. 64, p. 344-348, 2011.

CUNHA-LIGNON, M.; WOLF, T. C.; MENDONÇA, J. T. Conserved mangroves sustaining cultural diversity of traditional communities. IUCN Mangrove Symposium. Bremen, p. 30, 2017.

DEMAREST, A. Ancient Maya Civilization: The Rise and Fall of a Rainforest Civilization. Cambridge University Press: Cambridge, 2004.

DEPARTAMENTO DE ÁGUAS E ENERGIA ELÉTRICA (DAEE). Relatório Sistematização de base de dados ambientais do Complexo Estuarino-Lagunar de Iguape-Cananéia visando subsidiar regra operativa da Barragem do Valo Grande (Iguape). São Paulo, SP, 2011.

ELVIN, M. The Retreat of the Elephants: An Environmental History of China. Yale University Press: New Haven, 2004.

FREY, K. Políticas públicas: um debate conceitual e reflexões referentes à prática da análise de políticas públicas no Brasil. Planejamento e Políticas Públicas, n. 21, p. 212-259, 2000.

FERNANDES, G. W. et al. Deep into the mud: ecological and socio-economics impacts of the dam breach in Mariana, Brazil. Natureza e Conservação, v. 14, p. 35-45, 2016.

FERNÁNDEZ-ARMESTO, F. Millennium: A History of the Last Thousand Years. Touchstone: New York, 1995.

FURTADO, J. S.; YAMANAKA, N.; OLIVEIRA, M. C. Percepção ambiental e quadro referencial do complexo "Valo Grande e Sistema Lagunar Cananéia-Iguape”. São Paulo, SP, 1981. Disponível em: <ftp://ftp.sp.gov.br/ftppesca/sumula.pdf>. Acesso em: 02/01/2018

GIANNINI, P. C. F. et al. Morphology and Sedimentology of Ilha Comprida, Southern São Paulo Coast. In: DILLENBURG, S. R.; HESP, P. A. (Ed.). Geology and Geomorphology of Holocene Coastal Barriers of Brazil. Springer: Berlin-Heidelberg, p. 177-224, 2009. 
GIANNINI, P. C. F. et al. Contexto geológico e evolução sedimentar quaternária das barreiras costeiras e sistema estuarino-lagunar associado de Cananéia-Iguape-Ilha Comprida. In: MACHADO, R.; GÓES, A. M.; MORAES, M. C.; BARTORELLI, A. (Ed.). Setembrino Petri: do Proterozoico ao Holoceno. SBG: São Paulo, p.253-299, 2018.

GUEDES, C. C. F. et al. Determination of controls on Holocene barrier progradation through application of OSL dating: The Ilha Comprida Barrier example, Southeastern Brazil. Marine Geology, v. 285, p. 1-16, 2011.

GUSMÃO, J. S. P. Percepção e interação de comunidades caiçaras do complexo estuarino-lagunar de Iguapé-Cananéia, SP Brasil, com tartarugas marinhas. 2013. 104f. Dissertação (Mestrado em Diversidade Biológica e Conservação) - Universidade Federal de São Carlos.

HABERMAS, J. The Theory of Communicative Action: Vol. 1 (Reason and the rationalization of society). Heinemann: London, 1984.

HANAZAKI, N. et al. Between the sea and the land: the livelihood of estuarine people in southeastern Brazil. Ambiente \& Sociedade, v. 10, n. 1, p. 121-136, 2007.

HEMMING, J. Árvore de rios - A história da Amazônia. Senac: São Paulo, 2011.

ITALIANI, D. M.; MAHIQUES, M. M. O registro geológico da atividade antropogênica na região do Valo Grande, Estado de São Paulo, Brasil. Quaternary and Environmental Geosciences, v. 5, n. 2, p. 33-44, 2014.

MAHIQUES, M. M. et al. Anthropogenic influences in a lagoonal environment: A multiproxy approach at the valo grande mouth, Cananéia-Iguape system (SE Brazil). Brazilian Journal of Oceanography, v. 57, n. 4, p. 325-337, 2009.

MAHIQUES, M. M. et al. 150 years of anthropogenic metal input in a Biosphere Reserve: the case study of the Cananéia-Iguape coastal system, Southeastern Brazil. Environmental Earth Sciences, v. 68, n. 4, p. 1073-1087, 2013.

MAHIQUES, M. M. et al. Coastline changes and sedimentation related with the opening of an artificial channel: The Valo Grande Delta, SE Brazil. Anais da Academia Brasileira de Ciências, v. 86, n. 4, p. 1597-1607, 2014.

MARTÍNEZ, S.; MAHIQUES, M. M.; BURONE, L. Mollusks as indicators of historical changes in an estuarine-lagoonal system (Cananéia-Iguape, SE Brazil). The Holocene, v. 23, n. 6, p. 888-897, 2013.

MENNUCCI, S. O Porto de Iguape. O Observador, n. 70, p. 79-81, 1930

MISHIMA M. et al. Hidrografia do complexo estuarino-lagunar de Cananéia (25오 48 W), São Paulo, Brasil. Boletim do Instituto de Pesca, v. 12, n. 3, p. 109-121, 1985.

MINISTÉRIO DO MEIO AMBIENTE (MMA). Portaria no ${ }^{\circ}$ 150, de 8 de maio de 2006/ Diário Oficial da União. Brasília, DF, 2006.

MITTERMEIER, R. A. et al. Uma breve história da conservação da biodiversidade no Brasil. Megadiversidade, v.1, n. 1, p. 14-21, 2005. 
MOCCELLIN, J. A microbacia do rio Jacupiranguinha como unidade de estudos para a sustentabilidade dos recursos hídricos do baixo Ribeira de Iguape - SP. 2006. 135 f. Dissertação (Mestrado em Hidráulica e Saneamento) - Universidade de São Paulo.

NASCIMENTO JR. et al. Mudanças morfológicas da extremidade NE da Ilha Comprida (SP) nos últimos dois séculos. Revista do Instituto de Geociências - USP, v. 8, n. 1, p. 25-39, 2008.

OLIVEIRA, E. N. Estudo da pesca artesanal em dois setores do complexo estuarino-lagunar de Cananéia-Iguape (SP) considerando relações sócio-ambientais. 2011. $86 f$. Dissertação (Mestrado em Ciência Ambiental) - Universidade de São Paulo.

QUILTER, J. The Ancient Central Andes. Routledge Press: New York, 2014.

SANTOS, K. M. S.; TATTO, N. Agenda socioambiental de comunidades quilombolas do Vale do Ribeira. Instituto Socioambiental: São Paulo, 2008.

SILVA, J. I. A. O. Ecologização de megaprojetos hídricos: o caso da transposição do rio São Francisco. Agua y Territorio, n. 4, p. 59-69, 2014.

SOUZA, C. R. D. G. Praias arenosas oceânicas do estado de São Paulo (Brasil): síntese dos conhecimentos sobre morfodinâmica, sedimentologia, transporte costeiro e erosão costeira. Revista do Departamento de Geografia (USP), Volume Especial 30 anos, p. 307-371, 2012.

SOUZA, E. P. Canal do Valo Grande: Governança das águas estuarinas na perspectiva da aprendizagem social. 2012. 161f. Dissertação (Mestrado em Ciência Ambiental) Universidade de São Paulo.

SOUZA, T. A.; OLIVEIRA, R. C. Alterações ambientais no complexo estuarino-lagunar de Cananéia-Iguape: a influência do canal artificial do "Valo Grande". Boletim de Geografia (Maringá), v. 34, n. 3, p. 30-44, 2016.

TELES, A. A evolução geológica quaternária e a influência do Valo Grande na dinâmica sedimentar na área de Iguape, São Paulo. 1997. 98f. Dissertação (Mestrado em Estratigrafia e Sedimentologia) - Universidade de São Paulo.

THOMMEN, L. An Environmental History of Ancient Greece and Rome. Cambridge University Press: Cambridge, 2012.

TRAMONTE, K. M. et al. Geochemical behavior, environmental availability, and reconstruction of historical trends of $\mathrm{Cu}, \mathrm{Pb}$, and $\mathrm{Zn}$ in sediment cores of the Cananéia-Iguape coastal system, Southeastern Brazil. Marine Pollution Bulletin, v. 127, p. 1-9, 2018.

YOUNG, E. G. Subsídios para a História de Iguape. Revista do Instituto Histórico e Geográfico de São Paulo, v. 7, p. 286-298, 1902. Disponível em https://archive.org/ details/revistadoinstit07paulgoog. Acesso em 24 de maio de 2018.

. História de Iguape. Revista do Instituto Histórico e Geographico de São Paulo, v. 8, p. 222-340, 1903. 
VALENTIN, A. Uma civilização do arroz: agricultura, comércio e subsistência no Vale do Ribeira (1800-1880). 2006. 400f. Tese (Doutorado em História Econômica) - Universidade de São Paulo.

Submitted on: 24/07/2018

Accepted on: 07/10/2019

http://dx.doi.org/10.1590/1809-4422asoc0182r2vu19L4TD

2019;22:e01822

Featured Topics 


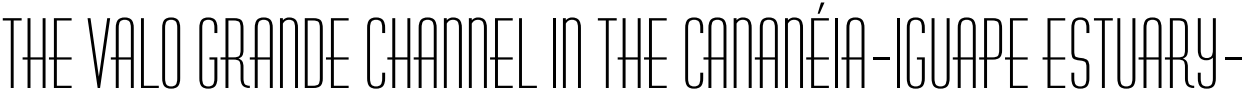

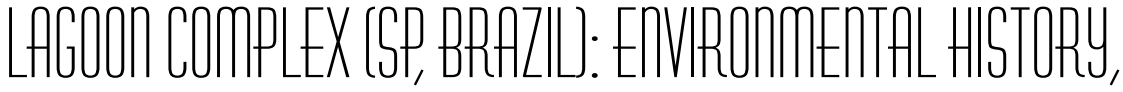 ECOLOCY, AПDUUUTURE PERSPECTINES
}

\author{
HELBERT MEDEIROS PRADO \\ MARCELO NIVERT SCHLINDWEIN \\ RUI SÉRGIO SERENI MURRIETA \\ DANIEL RODRIGUES DO NASCIMENTO JUNIOR \\ ELIEL PEREIRA DE SOUZA \\ MARILIA CUNHA-LIGNON \\ MICHEL MICHAELOVITCH DE MAHIQUES \\ PAULO CÉSAR FONSECA GIANNINI \\ RIGUEL FELTRIN CONTENTE
}

\section{O CANAL DO VALO GRANDE NO COMPLEXO ESTUARINO CANANÉIA-IGUAPE (SP, BRASIL): HISTÓRIA AMBIENTAL, ECOLOGIA E PERSPECTIVAS FUTURAS}

Resumo: Inaugurado em 1852, o canal artificial do Valo Grande (VG), no rio Ribeira de Iguape (SP), configura-se como um dos maiores desastres ambientais da costa brasileira. Este artigo apresenta uma síntese sobre o tema, abordando suas dimensões histórica, ecológica, geográfica e sociopolítica. O VG tem causado a desestruturação do ecossistema e a reconfiguração da paisagem no Complexo Estuarino-Lagunar Cananéia-Iguape. Estudos também indicam que parte dessas transformações pode ser reversível, caso o canal venha a ser fechado, como determinado em decisão judicial de $2^{a}$ Instância em 2018. Tal medida deverá ser acompanhada, no entanto, por um amplo programa de monitoramento visando sua efetividade (ambiental e social) em longo prazo. A questão do VG permanece ainda sem definição, passados mais de 150 anos desde os seus primeiros impactos significativos na região. Trata-se de fenômeno singular no Brasil e sobre o qual este artigo procura lançar alguma luz.

Palavras-chave: Vale do Ribeira; ambiente costeiro, rio Ribeira de Iguape; governança ambiental. 


\title{
THE VALO GRANDE CHANNEL IN THE CANANÉIA-IGUAPE ESTUARY-LAGOON COMPLEX (SP, BRAZIL): ENVIRONMENTAL HISTORY, ECOLOGY, AND FUTURE PERSPECTIVES
}

\begin{abstract}
The channel of the Valo Grande (VG) in the Ribeira de Iguape River (São Paulo State, Brazil), inaugurated in 1852, is one of the largest environmental disasters in the Brazilian coast. This article presents a synthesis of the historical, ecological, geographic and sociopolitical dimensions involving the VG. The VG has promoted the ecosystem disrupting and the landscape reconfiguration of Cananéia-Iguape estuary-lagoon complex. Studies have also indicated that part of these environmental changes could be reversible, in the case of VG closure, which was determined by Brazilian jury at second instance in 2018. Such a decision, however, shall be accompanied by an extensive monitoring program aiming at the environmental and social effectiveness of this action in long-term. The VG question still remains unsolved, although more than 150 years have passed since its first impacts in the region. It is a unique case in Brazil, which this article seeks shed some light.
\end{abstract}

Keywords: Ribeira Valley, coastal environment, Ribeira de Iguape River, environmental governance

\section{EL CANAL DEL VALO GRANDE EN EL COMPLEJO ESTUARINO \\ CANANEA-IGUAPE (SP, BRASIL): HISTORIA AMBIENTAL, ECOLOGÍA Y PERSPECTIVAS FUTURAS}

\begin{abstract}
Resumen: Inaugurado en 1852, el canal artificial del Valo Grande (VG), en el río Ribeira de Iguape (SP, Brasil), se configura como uno de los mayores desastres ambientales de la costa brasileña. Este artículo presenta una síntesis sobre el tema, abordando sus dimensiones histórica, ecológica, geográfica y sociopolítica. El VG ha causado la desestructuración del ecosistema y la reconfiguración del paisaje en el Complejo Estuarino-Lagunar CananéiaIguape. Los estudios también indican que parte de esas transformaciones puede ser reversible si el canal se cerraba, según lo determinado en decisión judicial de 2a Instancia en 2018. Tal medida deberá acompañarse, sin embargo, de un amplio programa de monitoreo para su efectividad (ambiental y social) a largo plazo. La cuestión del VG sigue siendo sin definición, pasados más de 150 años desde sus primeros impactos significativos en la región. Es un fenómeno único en Brasil, y sobre el cual este artículo busca arrojar alguna luz.
\end{abstract}

Palabras clave: Valle del Ribeira; ambiente costero, río Ribeira de Iguape; gobernanza ambiental 